\title{
Internships That Make A Difference: Two Campuses Continuous Internship Improvement Experience
}

Richard McCarthy, Quinnipiac University, USA Robert Petrausch, Iona College, USA

\begin{abstract}
Internships have been used by many academic programs to augment the student's educational experience. We discuss two internship programs that have been continuously refined in recent years to provide the students with a structured learning experience. We present a model for enriching student experiences by integrating internship experiences with academic experiences.
\end{abstract}

Keywords: education research, information systems education, public relations education, internships

\section{INTRODUCTION}

¿ can provide?

n many business and communications academic disciplines internships are included as a means to provide students with real-world experience. The internships are intended to augment existing curriculum to provide real world experience. But is that the only learning objective that a well planned internship

Pope (2000) points out that Goucher College in Towson, Maryland requires internships or foreign study from all of their students. They supplement this through a mentorship program that consists of alumni and other friends of the university that provide advice and help to open doors for students who are seeking internship opportunities. The internship is intended to be an enriching experience that is part of the overall academic experience. Pope goes on to point out that at Eckerd College in St. Petersburg, Florida they have a formal process in place to evaluate mentors each semester.

A highly structured internship program can benefit students by improving their ability to work on team projects and enhancing their skill in how they plan and complete activities.

We present two cases where structured internships have been utilized in the areas of information systems management and communications. We utilized an interdisciplinary approach to consider the extensibility of the approach to other areas of study within an academic program that will result in an enriching experience for the student.

\section{WHY INTERNSHIPS MATTER}

Knouse, Tanner and Harris (1999) found a relationship between college internships and college performance. Internships resulted in students being better prepared in the classroom and subsequently resulted in higher academic performance. Not surprisingly they also found a relationship between internships and subsequent job opportunities.

Fuller \& Schoenberger (1991) also found support for the relationship between academic performance and internships. Additionally, they found that the gender gap in salaries would have been higher had females not achieved higher academic success as a result of internships. 
Internships can be an effective way to improve a student's ability to work in teams. Although team based projects and activities are a regular part of the curriculum of many courses; students benefit from team-based internship activities by directly experiencing the impact of individual performance on the group and of group performance on the individual. Katzenbach and Smith (1993) point out "teams outperform individuals acting alone or in larger organizations or groupings, especially when performance requires multiple skills, judgments and experiences" (p.9). Lewis supported the importance of team performance and found face-to-face interaction resulted in greater team ability than groups that used electronic communication (Kozlowski \& Ilgen, 2007).

Sawyer (2007) identified seven characteristics of effective creative teams. They are:

1. Innovation emerges over time. Team members work together to build a chain of incremental ideas leading to a final solution.

2. Successful collaborative teams practice deep listening. Team members benefit from improving upon ideas and can put those ideas into practice.

3. Team members build upon their collaborative ideas. Team members support each other through iterative improvements.

4. Only afterwards does the meaning of each idea become clear. Team members understand the value of ideas through interaction with other team members.

5. Surprising questions emerge. Synergy begins to emerge. Teams members are more creative when ideas are translated into questions and problems.

6. Innovation is inefficient. There will be more misses than hits though when a hit occurs it can be a breakthrough.

7. Innovation emerges from the bottom up. Teams can be more creative by starting with details and working into a big picture.

The teamwork afforded students through internship opportunities enable them to develop and enhance their innovation skills. Innovation is not something that can be planned; it emerges when nurtured in the proper environment.

Petrausch (2007) defined the Maven Formula for creating compelling communications which can be used by college and workplace teams to create high performing teams (Mavens are experts who are called upon to recommend solutions). The Maven formula which can be experienced through internships can provide a mechanism to enable teams to improve performance and result in better academic performance. It consists of:

1. Messaging Systems consisting of key messages.

2. Audience Profile which provides a template for teams to understand the thinking styles of stakeholders who will accept and evaluate the project.

3. Visioning Processes that allow stakeholders to see the final result as completed and successful.

4. $\quad$ Emotional Connection that links the project stakeholders to the final result.

5. New Knowledge that is offered to achieve the project goal or solution. include:

Petrausch and McCarthy (2004) identified 9 characteristics of effective internship programs. These

1. Academic credit that is in part based upon the number of hours that were worked (to ensure that a student has enough time to achieve an enriching experience).

2. Internship sites that are with organizations that are committed to supporting the student's educational goals and not just looking for a cheap source of labor.

3. Internship supervisors that will serve as mentors to the student or that the organization has a formal mentoring program in place.

4. Experiential learning assignments are provided that track learning outcomes and can be measured to ensure that the student is achieving the internship goals.

5. An advisory council that shares ideas with faculty on improving internship experiences. 
6. Specialized training is made available to students when completing the internship.

7. The internship is linked to potential career opportunities to provide the student with additional incentive to succeed and to enhance their professional development skills.

8. The internships are promoted on campus to students who are freshman and sophomores so that they understand early on what their expectations will be.

9. Technology is used to promote the internship, including providing communications media as well as a means to capture an electronic portfolio of student experiences.

\section{INTERNSHIPS AS AN ACADEMIC EXPERIENCE}

The information systems management program at Quinnipiac University in Hamden, CT requires an internship experience for all of their majors. The internship requirement has developed over the years from a very informal work experience requirement to its present form; a highly structured academic experience. Initially the only objective of the internship was to provide students with some experience with how organizations operate by experiencing them first-hand. However, three years ago the program went through an extensive curriculum review and the decision was made to enhance the internship into an academic learning experience. The learning objectives for the internship include:

- $\quad$ To supplement and reinforce the students understanding of information technology concepts.

- To provide a forum for the student to understand how information technology works within an organization.

- $\quad$ To provide an opportunity for the student to demonstrate professional development skills.

- To enhance the students understanding of how organizations are managed and the role that information technology plays within that function.

- To provide an opportunity for the student to experience the information systems delivery process in a real world setting.

Since it is treated as an academic experience, it has a formal course syllabus, defined learning objectives, and specific outcomes that are designed to measure the student's progress against those objectives. A student cannot complete an internship until their junior year. They must first have completed a series of seminar courses that are required of all students in the school of business to provide them exposure to professional development, enhance their business communication skills, and identify diversity in the workplace issues.

Prior to beginning the internship the student is provided a formal syllabus. They must first prepare a research report on the company that they are going to work for. This consists of understanding the history of the company, its mission, strategic goals and objectives, an analysis of the industry that the firm competes in, a financial analysis of the health of the firm and an analysis of the objectives of the work group, department or division that the student will be a part of. This ensures that the student has an understanding of the organization that they are about to become a part of. In the event that no information about the company is available, then the student will complete the assignment by analyzing a competitor firm within that industry. The student is also required to critically review a current book from a pre-defined list of business best sellers (e.g., The World is Flat, Good to Great, Sarbanes-Oxley Guide for Finance and Information Technology Professionals). The purpose of the assignment is to broaden the student's exposure to business topics that have had an impact on their academic discipline.

Throughout the internship the student is required to maintain a journal of activities and experiences that critically review their internship responsibilities. In the past this consisted of a journal report; however it has more recently changed into a responsibility for the student to maintain a blog. They are given instruction as to content management prior to beginning the internship so that it is clear, concise and meaningful. All students in the information systems major have access to the blog; thereby giving them the opportunity to get a detailed view of several companies and the students experiences therein.

Finally, the students are required to complete a professional presentation of their experiences at the conclusion of the internship (This frequently happens at the beginning of the semester following the internship). 
The presentation is given to the sophomore-junior class so that they can get additional exposure and insight into prospective internship opportunities. In addition, each student is required to create a five minute narrated video that documents their internship experience. This library is made available to students for viewing.

\section{INTERNSHIPS AS APPLIED TEAM LEARNING}

The Torino Italy Olympic Games in 2006 hosted by NBC Universal was for many Iona College students the opportunity of a lifetime. NBC had hired 123 interns from college campuses in the United States and put them to work in jobs such as production support, press relations, research, accommodations, executives support, and as runners and loggers for the broadcast team. Eleven Iona students from the Mass Communication Department went to Torino to apply what they had learned in the classroom to a real-world setting at the Winter Olympic Games. They all participated in extensive briefings by NBC officials and would spend as much as ten to twelve hours a day on their assignments. The students collaborated with each other in various assignments working in a team setting and learning how to deliver results in real-time activities.

Iona College in New Rochelle, New York had set up a website for the students to post photographs, blogs, and journal entries about their experiences at the games. Students on campus could go to the website and find out what was happening at the Olympics based on students' reports and diaries. The students were able to participate in new media initiatives with broadband internet coverage the most technologically advanced of any Olympic Games. NBC had reported that Internet coverage increased from eight countries for Athens 2004 to over 20 across four continents. The students had learned about new media initiatives in the classroom and now they were witnessing those initiatives first hand in the field. They were learning about new High Definition Television (HD) features from the professionals at NBC as well as how to use HD cameras in the various venues. They could log on to an NBC Media Archive Site to search and find tapes of what was recorded that day at the various sports venues. They were also able to judge the enormous task of putting together the production for a major event on a global scale. This experience exposed student interns at Iona and other colleges to the high-stakes reality of new technologies at work and what they needed to learn about new media. Students who majored in broadcasting and public relations provided NBC web writers with updates and quotes for the various events and also updated information for the Daily Olympic newsletter.

\section{STUDENT LESSONS LEARNED AT THE TORINO OLYMPICS}

Iona students provided self reports at the end of their internship with NBC Universal. The following lessons were cited the most by the students.

1. Keep an Open Mind. This lesson was very useful given the multicultural setting of the Olympics and the many nationalities represented at the games.

2. Always challenge yourself. This lesson was important because students would often work harder (10-12 hours a day on assignment) than in a typical classroom day. Also, they had to remain open to new ideas and strategies.

3. Tackle each task with a smile. This lesson helped students remember that small jobs or tasks are often just as important as the big ones.

4. Don't be afraid to ask questions. With this lesson, students came to understand that professionals love explaining how they did something or how something works.

5. Share information and experiences with colleagues. This lesson taught students that by sharing information about themselves with others, they could gain valuable insight about human nature.

6. Try something new. Students discovered that by trying new things and even messing up once in a while, they could make major improvements at their assignments.

7. Leave your ego at the door. Students came to understand that big egos can derail teams and that teams need to work together in harmony to make things happen.

8. Give 120 percent to the effort. This lesson helped students understand that going the extra mile will make a big difference in the result of the project. 
9. Be a team player. This lesson helped students understand that complaining will not help the team move forward. Find the solution to the problem and make things happen.

10. Play to your strengths. Every team member has certain strengths. Learn what they are and use them on team assignments.

\section{DISCUSSION}

Although internships have been used for many years as a means to provide experienced-based learning and to support student post-graduation career goals; they have varied widely in their structure and learning outcomes. We posit that a highly structured internship program that emphasizes learning outcomes will have a significant impact on students both inside and outside the classroom. Activities must be structured to support the learning outcomes. To prepare students for this experience, they must begin to get an understanding of requirements and expected outcomes from the beginning of their freshman year. Positive internship experiences have been shown to also impact the students' academic experience. Since the structured internship experiences have begun, the student's who have completed these have reported that it has helped them to plan their individual work better, understand detail requirements more clearly and improve their performance in the classroom.

\section{AUTHOR INFORMATION}

Richard V. McCarthy (MBA, Western New England College, DBA, Nova Southeastern University) is a professor of Information Systems Management and the associate dean at the School of Business, Quinnipiac University. Prior to this, Dr. McCarthy was an associate professor of management information systems at Central Connecticut State University. He has twenty years of experience within the insurance industry and has held a Charter Property Casualty Underwriter (CPCU) designation since 1991. He has authored numerous research and pedagological information systems journal articles and contributed to the textbook Decision Support Systems and Intelligent Systems. His current research interest is in the area of enterprise architecture.

Dr. Robert J. Petrausch is an associate professor and head of the public relations sequence at Iona College in New Rochelle, New York. He is a former chief communications officer for Uniroyal Chemical and served in senior-level public relations positions with Shell Oil, GE, Sperry, and GTE. He is past President of the Westchester- Fairfield Chapter of the Public Relations Society of America and has served as PRSA Tri-State Chair. He is a consultant to Fortune 1000 companies and non-profits in the United States. He has a doctorate in education from the Department of Organization and Leadership at Columbia University in New York.

\section{REFERENCES}

1. Fuller, R. \& Schoenberger, R. (1991, December). The gender salary gap: do academic achievement, internship experience and college major make a difference?, Social Science Quarterly, 72(4), 715-726.

2. Katzenbach, J. \& Smith, D. (1993). The wisdom of teams. New York, NY: Harper Business.

3. Knouse, S., Tanner, J., Harris, E. (1999, March). The relation of college internships, college performance, and subsequent job opportunity, Journal of Employment Counseling 36(1), 35-43.

4. Kozlowski, S. W. J., Ilgen, D. R. (2007, June/July). The science of team success. Scientific American Mind, 54-59.

5. Petrausch, R. (2007). Building high-performance teams in the classroom and workplace: Learning from past mistakes, obstacles and missed opportunities, Proceedings of the New York State Communication Association Conference, New York, NY, October 18-20, 2007.

6. Petrausch, R. and McCarthy, R. (2004, January). A Multi-Disciplinary Examination of the Internship Experience: Setting up Programs that Work, proceedings of the College Teaching \& Learning Conference (TLC 2004), Orlando, FL, January 5-9, 2004.

7. Pope, L. (2000). Colleges that Change Lives: 40 Schools that you should know about even if you are not a Straight A Student. New York, NY: Penguin Books.

8. Sawyer, K. (2007). Group genius. Cambridge, MA: Basic Books. 
NOTES 